九州大学学術情報リポジトリ

Kyushu University Institutional Repository

Hetero-oligomerization of C2 domains of phospholipase C-related but catalytically inactive protein and synaptotagmin-1

王，大光

https://doi.org/10.15017/1500606

出版情報：九州大学，2014，博士（歯学），課程博士 バージョン:

権利関係：全文ファイル公表済 


\title{
Hetero-oligomerization of C2 domains of phospholipase C-related but catalytically inactive protein and synaptotagmin-1
}

\author{
DaGuang Wang a , Hiroshi Takeuchi ${ }^{\text {b, ** }}$, Jing Gao ${ }^{\text {a }}$, \\ Zhao Zhang ${ }^{\text {a, }}$, Masato Hirata ${ }^{\text {a, * }}$ \\ ${ }^{a}$ Laboratory of Molecular and Cellular Biochemistry, Faculty of Dental Science, Fukuoka 812-8582, Japan \\ ${ }^{\mathrm{b}}$ Division of Applied Pharmacology, Kyushu Dental University, Kitakyushu 803-8580, Japan \\ ' Stomatological Hospital of Hebei Medical University, Shijiazhuang 050017, PR China
}

Keywords:

Synaptotagmin

C2 domain

Rabphiline

Syntaxin

SNARE

SNAP-25

\section{A B S T R A C T}

The $\mathrm{C} 2$ domain is a protein module often found in molecules that regulate exocytosis. $\mathrm{C} 2$ domains mediate interactions between the parental molecule and $\mathrm{Ca}^{2+}$, phospholipids, and proteins. Although various molecules have been shown to interact with several C2 domains, no interactions between the $\mathrm{C} 2$ domains from different molecules have yet been reported. In the present study, we identified direct interactions between the C2 domain of PRIP (phospholipase C-related but catalytically inactive protein) and the C2 domains of other molecules. Among the C2 domains examined, those of synaptotagmin-1 (Syt1-C2A and Syt1-C2B) and phospholipase $C \delta-1$ bound to the $C 2$ domain of PRIP. We investigated the interactions between the $\mathrm{C} 2$ domain of PRIP (PRIP-C2) with Syt1-C2A and Syt1-C2B, and the mode of binding of each was $\mathrm{Ca}^{2+}$-dependent and -independent, respectively. We further demonstrated that the $\mathrm{Ca}^{2+}$ dependence of the interaction between PRIP-C2 and Syt1-C2A was attributed to $\mathrm{Ca}^{2+}$ binding with Syt1-C2A, but not PRIP-C2, using a series of mutants prepared from both $\mathrm{C} 2$ domains. We previously reported that the interaction between PRIP-C2 and the membrane fusion machinery suggested a

Abbreviations: SNARE, soluble NSF (N-ethylmaleimide-sensitive factor)-attachment protein receptors; SNAP-25, synaptosomeassociated protein of $25 \mathrm{kDa}$; Syt, synaptotagmin; PLC, phospholipase C; PRIP, phospholipase C-related but catalytically inactive protein; Rph, rabphilin-3A; GST, glutathione S-transferase.

* Corresponding author. Tel.: +8192642 6317; fax: +81926426322.

** Corresponding author. Tel.: +8193285 3053; fax: +81935826000.

E-mail addresses: r12takeuchi@fa.kyu-dent.ac.jp (H. Takeuchi), hirata1@dent.kyushu-u.ac.jp (M. Hirata). 
critical role for PRIP in exocytosis; therefore, the results of the present study further support the importance of PRIP-C2 in the inhibitory function of PRIP in regulating exocytosis.

() 2014 Elsevier Ltd. All rights reserved.

\section{Introduction}

The secretion of neurotransmitters, neuropeptides, and peptide hormones, and also the exposure of membrane proteins such as receptors, channels, and transporters to the cell surface are mediated by the fusion of vesicles with the plasma membrane, namely the final step of exocytosis. The minimal machinery required for cellular membrane fusion are the hetero-trimeric complexes of SNARE [soluble NSF ( $N$-ethylmaleimide-sensitive factor)-attachment protein receptors] proteins (Hong, 2005; Malsam et al., 2008; Weber et al., 1998), which consist of members of the VAMP (vesicle-associated membrane protein, also called synaptobrevin) family on the vesicular membrane (v-SNARE) as well as syntaxin and synaptosome-associated protein of $25 \mathrm{kDa}$ (SNAP-25) families on the target plasma membrane ( $\mathrm{t}-$ SNARE). A number of accessory proteins that directly interact with individual SNARE proteins and/or with assembled SNARE protein complexes are also indispensable for the tight control of SNAREmediated membrane fusion triggered by increases in cytoplasmic $\mathrm{Ca}^{2+}$ (Bai and Chapman, 2004; Carr and Rizo, 2010; Deak et al., 2006; Friedrich et al., 2008; James et al., 2009; Walter et al., 2011). Synaptotagmin-1 (Syt1) is the best characterized accessory protein that confers $\mathrm{Ca}^{2+}$ sensitivity to vesicle exocytosis by modulating its own $\mathrm{Ca}^{2+}$-dependent intermolecular interactions, including acidic phospholipids and fusion machinery, such as phosphatidylserine, phosphatidylinositol 4,5bisphosphate [PtdIns(4,5) $\mathrm{P}_{2}$ ], and SNARE proteins (Brose et al., 1992; Chapman, 2002; Rizo et al., 2006; Sudhof, 2002). Synaptotagmin-1 is a member of synaptotagmin family, comprises an N-terminal transmembrane domain and two cytoplasmic C2 domains (membrane-proximal, C2A and membrane-distal, $\mathrm{C} 2 \mathrm{~B}$ ), and attributes its $\mathrm{Ca}^{2+}$-dependent properties to the $\mathrm{C} 2$ domains. These tandem $\mathrm{C} 2$ domains collaborate to exert $\mathrm{Ca}^{2+}$-dependent and independent molecular interactions, however, Syt1-C2A mediates $\mathrm{Ca}^{2+}$-dependent phospholipid binding (Chapman and Jahn, 1994; Davletov and Sudhof, 1993) while Syt1-C2B mediates $\mathrm{Ca}^{2+}$-independent interactions with AP-2, as well as $\beta$-SNAP (Schiavo et al., 1995), inositol polyphosphates (Fukuda et al., 1994; Schiavo et al., 1996), and the synprint region of N- and P/Q-type $\mathrm{Ca}^{2+}$ channels (Kim and Catterall, 1997; Sheng et al., 1997). Syt1-C2B has also been shown to mediate the homo-oligomerization of synaptotagmins in collaboration with the phospholipid binding of Syt1-C2A (Wu et al., 2003). Three and two $\mathrm{Ca}^{2+}$ ions bind to the C2A and C2B of Syt1, respectively, and are coordinated by five acidic residues (Asp) conserved in loops 1 and 3 of the eight-stranded $\beta$-sandwich (Fernandez et al., 2001; Fernandez-Chacon et al., 2001; Sutton et al., 1995, 1999; Ubach et al., 1998).

Phospholipase C-related but catalytically inactive protein (PRIP), which was named for its lack of catalytic activity in spite of its structural similarity to phospholipase C (PLC)- $\delta 1$ (Kanematsu et al., 1992, 1996), was originally isolated as an inositol 1, 4, 5-trisphosphate $\left[\operatorname{Ins}(1,4,5) \mathrm{P}_{3}\right]$ binding protein in our laboratory. PRIP consists of a pleckstrin homology (PH) domain, EF-hand motifs, $\mathrm{X}$ and Y motifs, and a $\mathrm{C} 2$ domain, and has been shown to interact with a number of partners including GABARAP $[\gamma$-aminobutyric acid type $A\left(G_{A B A}\right)$ receptor-associated protein] (Kanematsu et al., 2002; Uji et al., 2002), the $\beta$ subunit of the $\mathrm{GABA}_{\mathrm{A}}$ receptor (Kanematsu et al., 2006, 2007), the catalytic subunit of protein phosphatase $1 \alpha$ (PP1 $\alpha$ ) and PP2A (Yoshimura et al., 2001; Kanematsu et al., 2006; Sugiyama et al., 2012; Sgiyama et al., 2013), and the phosphorylated (active) form of Akt (Fujii et al., 2010), in addition to Ins (1,4,5) $\mathrm{P}_{3}$ and PtdIns(4,5) $\mathrm{P}_{2}$ to the PH domain (Takeuchi et al., 1996, 2000). It was of particular interest that PRIP might participate in a phospho-regulation of variety of cellular functions by swapping phosphatases between PP1 and PP2A, depending on a phospho-state of PRIP itself (Sugiyama et al., 2012; Sgiyama et al., 2013). We generated knock-out (KO) mice lacking each or both of the known isoforms of PRIP (type 1 and type 2) in order to explore the biological roles in relation to these interacting proteins. Among the phenotypes we reported for PRIP-KO mice (Doira et al., 2001; Fujii 
et al., 2010; Kanematsu et al., 2002, 2006, 2007; Matsuda et al., 2009), an increase in the exocytosis of various peptide hormones such as gonadotropins and insulin (Doira et al., 2001; Matsuda et al., 2009) prompted us to focus on the inhibitory role of PRIP in exocytosis. Subsequent studies suggested that PRIP may be involved in the negative regulation of exocytosis through multiple molecular interactions. The interaction between the $\mathrm{PH}$ domain and $\operatorname{Ptd} \operatorname{Ins}(4,5) \mathrm{P}_{2}$, which was shown to be required for vesicle exocytosis (Hay and Martin, 1993; Holz et al., 2000; James et al., 2008), supported PRIP being enriched near the site of the event. We recently reported that although the PRIP-C2 domain very weakly interacted with phospholipids, it interacted with t-SNARE proteins more strongly and in a $\mathrm{Ca}^{2+}$ dependent manner. The C2 domain was required for the co-localization of PRIP with t-SNAREs in cells. Moreover, the $\mathrm{C} 2$ domain was found to have direct inhibitory effects on the formation of ternary SNARE complexes and on participation of synaptotagmin (Zhang et al., 2013). Thus, since membrane microdomains for exocytosis contain PtdIns $(4,5) \mathrm{P}_{2}$ and the t-SNARE component proteins, syntaxin 1 and SNAP-25, we concluded that PRIP exhibited its inhibitory role by the combination of its PH and C2 domain binding to PtdIns $(4,5) \mathrm{P}_{2}$ and t-SNAREs, respectively. In the course of these experiments, we also found that PRIP-C2 directly interacted with the C2 domains of Syt1.

In the present study, we investigated the underlying mechanisms for the direct interactions between PRIP-C2 and the isolated C2 domains of Syt1 in order to clarify the amino acid residues/interface involved in these interactions. We previously showed that PRIP-C2 competed with Syt 1 for t-SNARE proteins in the previous report (Zhang et al., 2013); the results obtained herein may provide a deeper understanding of the relationship between PRIP, Syt1, and t-SNARE proteins.

\section{Materials and methods}

\section{Materials}

The antibodies to each protein in this study were as follows: SNAP-25 (Abcam, Cambridge, MA), syntaxin 1, GST (Santa Cruz Biotechnology, Santa Cruz, CA). An anti-PRIP-1 rabbit polyclonal antibody was prepared in this laboratory as described previously (Kanematsu et al., 2002).

\section{Preparation of expression constructs and site-directed mutagenesis of the C2 domains}

The preparation of all expression constructs for the C2 domains, SNAP-25, and syntaxin- 1 has been described in detail elsewhere (Gao et al., 2012; Zhang et al., 2013). Mutants carrying substitutions of amino acid residues were produced using the QuikChange site-directed mutagenesis kit (Agilent Technologies, Santa Clara, CA). All constructs were fully sequenced to verify their integrity at the Research Support Center of the Graduate School of Medical Sciences at Kyushu University. More details on all constructs are available on request. GST (glutathione S-transferase)- or His-tagged proteins were prepared using a bacterial expression system as described previously (Takeuchi et al., 2000). The absence of contamination by oligonucleotides from bacteria in the isolated recombinant $\mathrm{C} 2$ domains used in this study was confirmed by measuring the UV spectrum of each preparation, which had a UV absorption maximum at $280 \mathrm{~nm}$, not $260 \mathrm{~nm}$.

\section{GST pull-down assay}

GST pull-down assays were performed as described previously (Zhang et al., 2013) with some minor modifications. Briefly, $10 \mathrm{pmol}$ of the GST-fused protein and His-tagged protein or proteins prepared as GST-fusion proteins followed by thrombin digestion to remove the GST tag were mixed in $200 \mu \mathrm{l}$ of the assay buffer, which consisted of $10 \mathrm{mM}$ Hepes- $\mathrm{KOH}, \mathrm{pH} 7.3,100 \mathrm{mM} \mathrm{KCl}, 3.5 \mathrm{mM} \mathrm{MgCl} 2,1 \mathrm{mM}$ EGTA, $0.1 \%$ Nonidet P- 40 , and $1 \mathrm{mM}$ dithiothreitol, and was incubated at $4{ }^{\circ} \mathrm{C}$ for $3 \mathrm{~h}$. GST-fused proteins were then collected by incubating the mixture with glutathione-Sepharose $4 \mathrm{~B}$ (GE Healthcare) at $4{ }^{\circ} \mathrm{C}$ for an additional hour. After being incubated, the beads were washed with the same buffer four times to remove unbound proteins and then subjected to SDS-polyacrylamide gel electrophoresis followed by Western blotting analysis. To examine the effects of $\mathrm{Ca}^{2+}$ on binding, the assays were performed in the same buffer as described above, but in the presence of a calculated amount of $\mathrm{Ca}^{2+}$ to give a free $\mathrm{Ca}^{2+}$ 
concentration of $10 \mu \mathrm{M}$ or buffer containing $1 \mathrm{mM}$ EGTA. An equivalent amount of the GST-fused protein in each assay mixture was confirmed by detection with the anti-GST antibody and Coomassie Brilliant Blue staining of the membrane.

\section{Results and discussion}

\section{Direct interactions between the C2 domain of PRIP and other C2 domains}

While determining the molecular mechanism underlying how PRIP regulated exocytosis through interactions between its multiple domains and other molecules following the finding that PRIP-C2 interacted with t-SNARE proteins (Zhang et al., 2013), we also found that the C2 domain of PRIP bound to the C2 domain of Syt-1. To confirm this specific interaction, we performed GST pull-down assays using isolated $\mathrm{C} 2$ domains from several molecules. His-PRIP-C2 clearly bound to GST-tagged Syt1-C2A, and Syt1-C2B, and to a lesser extent to PRIP-C2 and the C2B domain of rabphilin-3A (Rph-C2B), whereas no binding was observed to GST alone (Fig. 1A). Among these C2 domains, PRIP$\mathrm{C} 2$ showed $\mathrm{Ca}^{2+}$ dependence when binding to Syt1-C2A only. Bacterial contaminants have been shown to tightly bind to the polybasic sequence of the $\mathrm{C} 2$ domain in order promote oligomerization of the C2 domain (Ubach et al., 2001). Therefore, we measured the UV spectrum of the isolated C2 domains used in the present study and confirmed that all preparations had UV absorption maxima at $280 \mathrm{~nm}$, not $260 \mathrm{~nm}$. Furthermore the ratio of absorption at $280 \mathrm{~nm}$ to that at $260 \mathrm{~nm}$ was

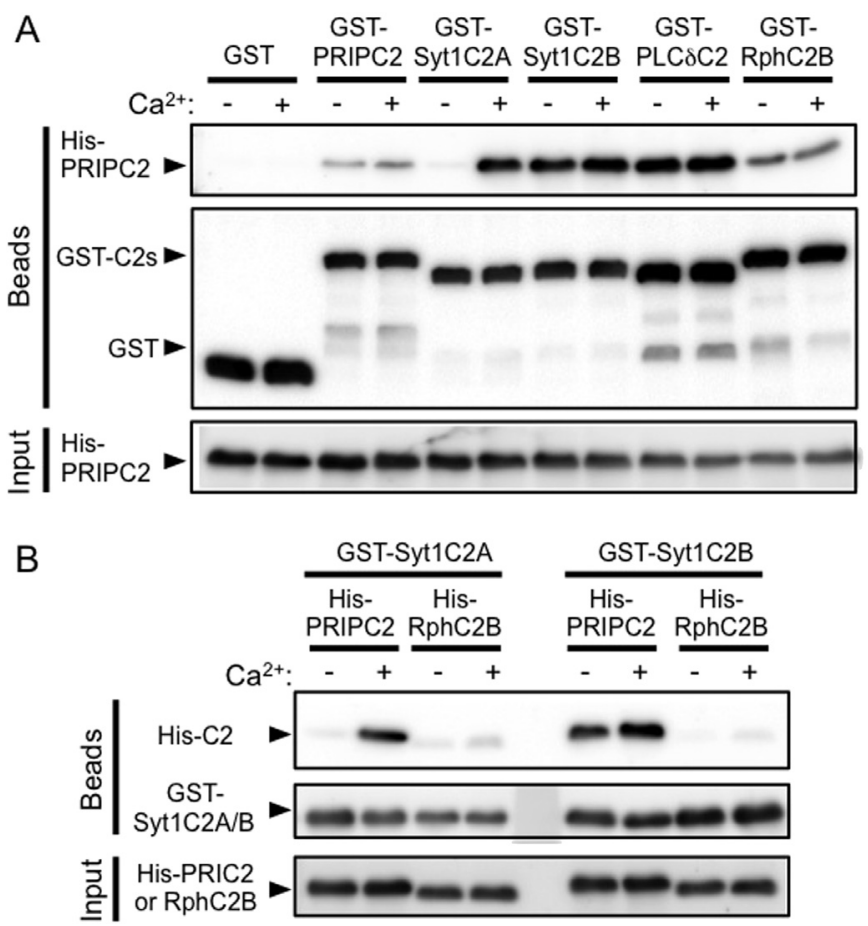

Fig. 1. Interaction between PRIP-C2 and various C2 domains. A: A mixture of 10 pmol each of His-tagged PRIP-C2 with GST or GSTfused C2 domains (PRIP-C2, Syt1C2A, Syt1C2B, PLC $\delta C 2$, and RphC2B) was incubated in the presence or absence of $\mathrm{Ca}^{2+}$, as described in the Materials and Methods, at $4{ }^{\circ} \mathrm{C}$ for $3 \mathrm{~h}$ and was then applied to glutathione beads. After being incubated for an additional hour, the beads were washed extensively, followed by Western blotting. His-tagged PRIP-C2 that remained on the beads (top panel) and in the mixture before the addition of the beads (bottom panel for input) was detected by an anti-PRIP rabbit polyclonal antibody that recognizes PRIP-C2. GST-fused proteins on the beads were detected by an anti-GST antibody. B: A GST pull-down assay was performed as in A. His-tagged C2 domains that remained on the beads were detected with an anti-His antibody. 
approximately 1.8 , indicating negligible bacterial contamination. This was also confirmed in a subsequent experiment in which the binding of His-Rph-C2B to GST-Syt1-C2 was compared with that of PRIP-C2 (Fig. 1B). PRIP-C2 showed $\mathrm{Ca}^{2+}$-dependent and -independent binding to Syt1-C2A and Syt1C2B, respectively, while Rph-C2B bound to neither Syt1-C2A nor Syt1-C2B in the presence or absence of $\mathrm{Ca}^{2+}$. The integrity of the preparation of His-Rph-C2B was previously demonstrated by its specific binding to SNAP-25 (Zhang et al., 2013); therefore the absence of interactions between RphC2B and Syt1-C2A or Syt1-C2B may not be attributed to the defective conformation of His-Rph-C2B. Thus, the results shown in Fig. 1B also showed that the ability to form hetero-oligomers with Syt1C2A and Syt1-C2B was specific to PRIP-C2.

\section{Comparison of the binding profile of PRIP-C2 to Syt1-C2A and Syt1-C2B}

Increases in PRIP-C2 binding to Syt1-C2A and Syt1-C2B were examined using a GST pull-down assay (Fig. 2A and B). The binding of PRIP-C2 to each C2 domain increased in a dose-dependent manner. The $E C_{50}$ (effective concentration required for a $50 \%$ effect) values for PRIP-C2 binding to Syt1-C2A in the presence or absence of $\mathrm{Ca}^{2+}$ were $100 \mathrm{nM}$ and $4.5 \mu \mathrm{M}$, respectively (Fig. 2A). On the other hand, the binding of PRIP-C2 to Syt1-C2B was not significantly affected by the presence of $\mathrm{Ca}^{2+}$, i.e., the $E C_{50}$ values for PRIP-C2 binding to Syt1-C2B in the presence or absence of $\mathrm{Ca}^{2+}$ were $80 \mathrm{nM}$ and $200 \mathrm{nM}$, respectively (Fig. 2B). These binding profiles of PRIP-C2 to the C2 domains of Syt1 were compatible with the $\mathrm{Ca}^{2+}$ dependence of the binding observed in Fig. $1 \mathrm{~A}$ and $\mathrm{B}$. We previously reported that the $E C_{50}$ values of PRIP-C2 to syntaxin-1 and SNAP-25 were $1.1 \mu \mathrm{M}$ and $1.9 \mu \mathrm{M}$, respectively, using a similar assay procedure (Zhang et al., 2013). A simple comparison of these $E C_{50}$ values indicated that PRIP-C2 had higher affinity to the C2 domains of Syt 1 than to those of the t-SNARE proteins. Therefore, the inhibitory effects of PRIP-C2 on the binding of Syt1 to tSNARE proteins may be mediated not only by PRIP-C2 binding to t-SNARE proteins competitively with Syt1, but also, or even rather by PRIP-C2 binding to Syt1 competitively with t-SNARE proteins. We also performed the same experiment using GST-Syt1-C2AB (tandem) and obtained $E C_{50}$ values for PRIP-C2 binding of $0.8 \mu \mathrm{M}$ and $2.3 \mu \mathrm{M}$ in the presence and absence of $\mathrm{Ca}^{2+}$, respectively, which was similar to Syt1-C2B, but with higher $E C_{50}$ values (Fig. $2 \mathrm{C}$ ). These $E C_{50}$ values were similar with those to t-SNARE proteins, suggesting that the binding affinity of PRIP-C2 to Syt1-C2AB was similar to that to t-SNARE proteins.

\section{Effects of site-directed mutagenesis on the relationship between pairs involving PRIP-C2}

To investigate the relationships among PRIP, Syt1, and SNAP-25 and/or syntaxin 1, we attempted to identify the residues/interface essential for the interaction between each pair of these molecules. We prepared PRIP-C2 mutants with reference to the sequence alignment of the C2 domains (Fig. 3 ) and examined binding to Syt1-C2A and C2B (Table 1A). Since the acidic residues conserved in loops 1 and 3 of the $\mathrm{C} 2$ domains to accommodate $\mathrm{Ca}^{2+}$ ions were almost conserved in PRIP-C2, we prepared neutralized mutants in which these acidic residues were replaced with asparagine and examined binding to Syt1-C2 domains. However, even when all three residues in loop 3 were replaced (D801N/ D803N/E808N), the binding of PRIP-C2 to Syt1-C2A and C2B was not reduced. We further neutralized additional acidic residues adjacent to those in loop 3 of PRIP-C2 (D801/802/803/807N/E808N) and examined binding to Syt1-C2A and C2B. This neutralization had a negligible effect on the $\mathrm{Ca}^{2+}$ dependent interaction between PRIP-C2 and the C2 domain of Syt1 (Table 1A). Although only one out of two aspartate residues was conserved in loop 1, it was analogous to the C2 domain of PLC- $\delta 1$, which was shown to bind $\mathrm{Ca}^{2+}$ (Essen et al., 1997). Furthermore, in loop 3 of PRIP-C2, one of the three conserved aspartates was replaced by glutamate (E808, Fig. 4). However, a structural analysis of Rph$\mathrm{C} 2 \mathrm{~A}$, in which a glutamate was instead present and at the position of one of the three conserved aspartate residues similar to PRIP, revealed that glutamate could be directly involved in the recognition of $\mathrm{Ca}^{2+}$ by Rph-C2A (Coudevylle et al., 2008). Thus, the acidic residues in loops 1 and 3 of PRIP-C2, candidates for accommodating $\mathrm{Ca}^{2+}$ ions, may not have been involved in the $\mathrm{Ca}^{2+}$-dependent binding of PRIP-C2 to Syt1-C2. Since the basic residues in the $\beta 4$-strand of Syt1-C2 were shown to be involved in the interaction between Syt1 and the SNARE complex, the basic residues close to the 

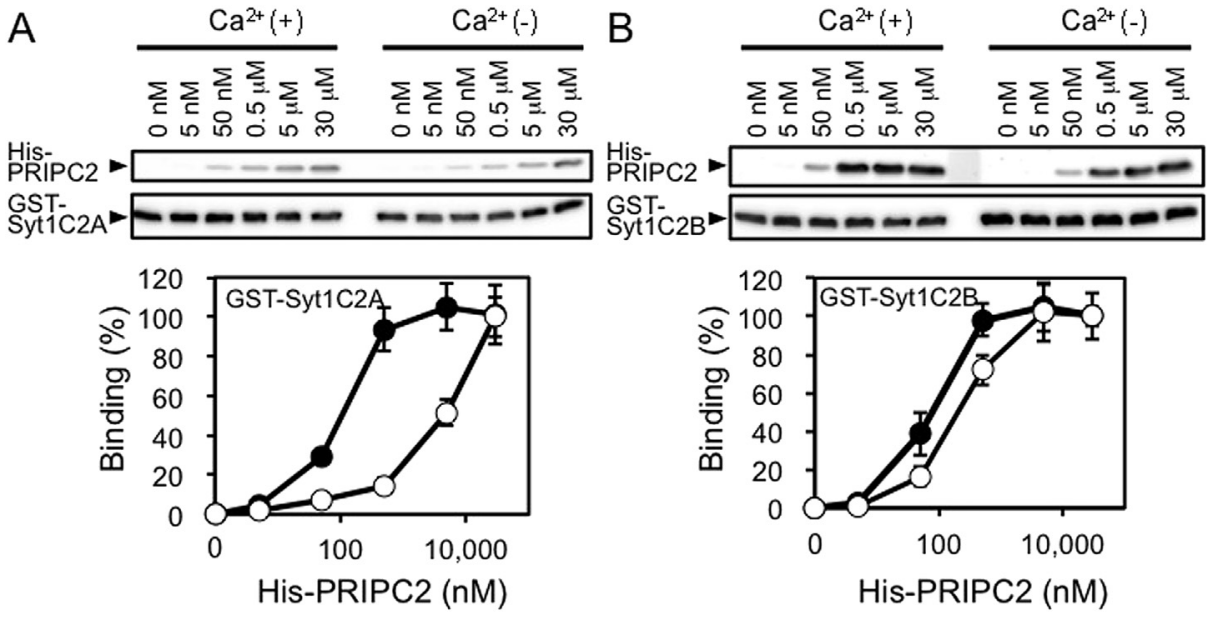

His-PRIPC2 (nM)
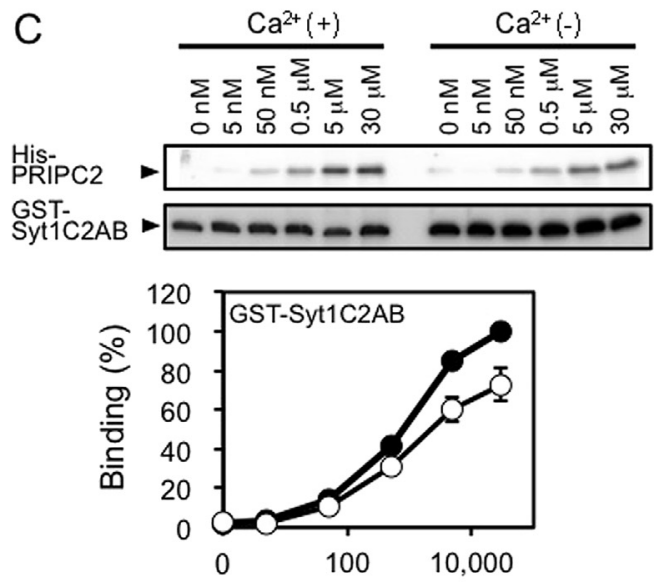

His-PRIPC2 (nM)

Fig. 2. Comparison of binding profiles of the PRIP-C2 domain to the C2 domains of Syt1. A GST pull-down assay was performed as described in Fig. 1, except that the mixture contained the indicated concentrations of His-PRIP-C2 and 10 pmol of GST-Syt1-C2 (A: GST-Syt1-C2A, B: GST-Syt1-C2B, C: GST-Syt1-C2AB). Each data point is the mean \pm SE of at least 3 independent experiments with 2 immunoblots for each experiment.

corresponding site in PRIP-C2 were also mutated (R766Q/K768Q), indicating that PRIP-C2 may be recognized as an effector molecule by Syt1: however, the results obtained showed that the binding of PRIP-C2 to either Syt1-C2A or Syt1-C2B was unaffected.

We subsequently prepared several mutants of Syt1-C2A and C2B and examined binding to PRIP-C2. The binding of the mutants with the PRIP-C2 and SNARE proteins is summarized in Table 1B. The neutralization of acidic residues either in loop 1 (D178N) or loop 3 (D230/232A) completely abolished the $\mathrm{Ca}^{2+}$-dependent binding of Syt1-C2A to PRIP-C2 (Fig. 4), suggesting that the $\mathrm{Ca}^{2+}$ dependence of the interaction between PRIP-C2 and Syt1-C2 (Fig. 2A) may be attributed to the conserved $\mathrm{Ca}^{2+}$ binding residues of Syt1-C2A. It currently remains unclear whether the PIRP-C2 interaction with Syt1-C2A affected the $\mathrm{Ca}^{2+}$-dependent phospholipid binding of Syt1-C2A. On the other hand, any conserved aspartate residues in Syt1-C2B were not involved in binding to PRIP-C2 (Table 1B), which was consistent with the interaction between PRIP-C2 and Syt1-C2B being $\mathrm{Ca}^{2+}$-independent (Fig. 2B). This 


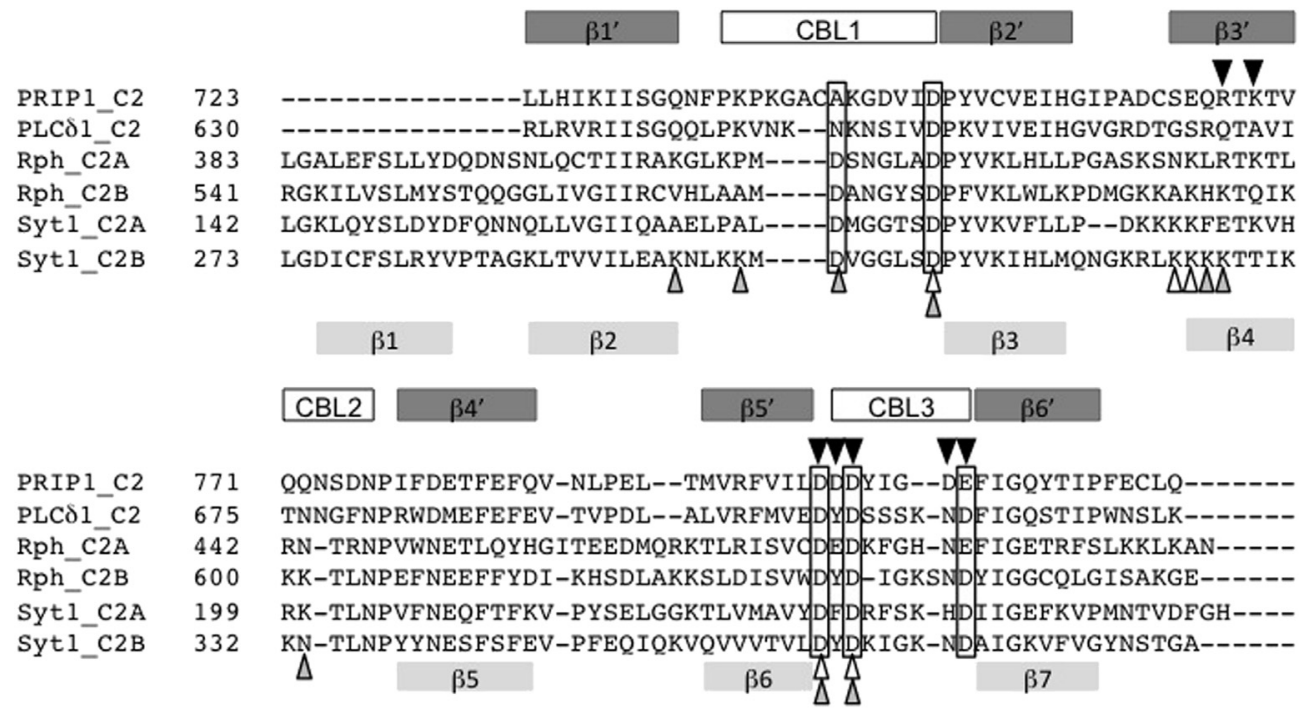

$\begin{array}{lll}\text { PRIP1_C2 } & 822 & \text { PGYRHVPLRSFVGDIMEH-VTLFVHIAITN } \\ \text { PLC } 1 \text { 1_C2 } & 728 & \text { QGYRHVHLLSKNGDQHPS-ATLFVKISIQD } \\ \text { Rph_C2A } & 498 & \text { QRKWFWICLERV } \\ \text { Rph_C2B } & 654 & \text { RLKHWYECLKNK } \\ \text { Syt1_C2A } & 255 & \text { VTEEWRDLQSAE } \\ \text { Syt1_C2B } & 386 & \text { ELRHWSDMLANP } \\ & & \beta 8\end{array}$

\begin{tabular}{lc}
\multicolumn{1}{c|}{$\beta 7^{\prime}$} & \\
PGYRHVPLRSFVGDIMEH-VTLFVHIAITN & \\
QGYRHVHLLSKNGDQHPS-ATLFVKISIOD & $\boldsymbol{\nabla}:$ :PRIPC2 \\
QRKWFWICLERV & $\Delta:$ :Syt1C2A \\
RLKHWYECLKNK & $\Delta:$ :Syt1C2B \\
VTEEWRDLQSAE & \\
ELRHWSDMLANP &
\end{tabular}

Fig. 3. Sequence alignment of $C 2$ domains. The amino acid sequences of the $C 2$ domains were aligned using ClustalW2 (http://www. ebi.ac.uk/Tools/msa/clustalw2/) and minor corrections were applied manually. The positions of the conserved aspartate residues for coordinating $\mathrm{Ca}^{2+}$ are boxed. The secondary structures of type I and type II topologies (Nalefski, E. A., and Falke, J. J. (1996) Protein science $5,2375-2390)$ are schematically shown above and below the sequence, respectively. The three loops involved in $\mathrm{Ca}^{2+}$ binding are shown above as CBL1, 2, and 3. The GenBank accession numbers of the parental proteins are rat PRIP-1; NP445908, rat PLC- $\delta 1$; NP058731, rat synaptotagmin I; NP001028852, rat rabphilin 3A; NP598202. The amino acid residues mutated in this study are indicated by arrowheads: PRIP-C2, arrowheads filled with black; Syt1-C2A, open arrowheads; Syt1-C2B, arrowheads filled with gray.

result was analogous to that from the mutagenesis experiment for Syt1-C2B in which the simultaneous neutralization of four (D303, 309, 363, 365N) acidic $\mathrm{Ca}^{2+}$ ligands resulted in $\mathrm{Ca}^{2+}$-independent constitutive clustering activity, but did not affect binding to the effector molecules, AP-2 and synprint (Desai et al., 2000). We then replaced the other residues of Syt1-C2B, which were shown to be involved in binding with other protein targets, and all of them failed to abolish the interaction with PRIP-C2 (Table 1B). For example, lysines 326 and 327 were previously reported to be critical for the binding of Syt1 to AP-2 as well as the synprint region of $\mathrm{Ca}^{2+}$ channels, in addition to the homooligomerazation and substitution of both these lysines with alanine residues essentially abolishing all these interactions (Chapman et al., 1998). Although it was later shown that the lysine residues at positions 326 and 327 served as sites for strong interactions with bacterial contaminants (Ubach et al., 2001), which suggested that the contaminant may affect any behavior of the C2B, a UV spectrum analysis of the preparations used in the present study revealed that they did not contain any amount of nucleotides. It currently remains unclear how the $\mathrm{Ca}^{2+}$-independent interaction between PRIP-C2 and Syt1-C2B is mediated, because none of the mutations introduced in the present study affected this interaction. 
Table 1

Summary of binding regarding the effects of amino acid substitutions of PRIP-C2 and Syt1-C2. A GST pull-down assay was performed in the presence or absence of $\mathrm{Ca}^{2+}$ as in Fig. 1, using combinations of His-PRIP-C2 mutants and GST-Syt1-C2A or C2B (A); GST-fused Syt1-C2A and Syt1-C2B mutants with the wild-type His-PRIP-C2 (B). The intensities of the bands indicating binding were analyzed by NIH ImageJ software. '+', binding was similar to that of the wild-type C2 in the presence of $\mathrm{Ca}^{2+}$; '-', very weak or no detectable binding.

\begin{tabular}{|c|c|c|c|c|c|}
\hline \multicolumn{6}{|l|}{ A } \\
\hline \multirow[t]{2}{*}{ His-PRIP-C2 } & & \multicolumn{2}{|c|}{ Syt1-C2A } & \multicolumn{2}{|c|}{ Syt1-C2B } \\
\hline & $\mathrm{Ca}^{2+}:$ & - & + & - & + \\
\hline WT & & - & + & + & + \\
\hline D748N & & - & + & + & + \\
\hline R766Q/K768Q & & - & + & + & + \\
\hline $\mathrm{D} 801 / 803 \mathrm{~N}$ & & - & + & + & + \\
\hline D808N & & - & + & + & + \\
\hline D801/803/808N & & - & + & + & + \\
\hline D801/802/803/807/E808N & & - & + & + & + \\
\hline \multicolumn{6}{|l|}{ B } \\
\hline & \multirow[t]{2}{*}{ GST-Syt1A/B } & & \multicolumn{3}{|c|}{ PRIP-C2 } \\
\hline & & & & \multicolumn{2}{|l|}{-} \\
\hline \multirow[t]{4}{*}{ GST-Syt1-C2A } & \multicolumn{3}{|l|}{ WT } & - & + \\
\hline & D178N & & & - & - \\
\hline & \multicolumn{2}{|l|}{ K191/192A } & & \multirow[b]{2}{*}{-} & + \\
\hline & D230/232A & & & & - \\
\hline \multirow{7}{*}{ GST-Syt1-C2B } & WT & & & + & + \\
\hline & K297/301Q & & & + & + \\
\hline & D303N & & & + & + \\
\hline & D309N & & & + & + \\
\hline & K326/327A & & & + & + \\
\hline & N333T & & & + & + \\
\hline & D363/365A & & & + & + \\
\hline
\end{tabular}

\section{Conclusions}

We showed that PRIP-C2 formed a hetero-oligomer with the C2 domains of other molecules and investigated the binding profiles of PRIP-C2 with Syt1-C2A and Syt1-C2B. This is the first study to show a direct interaction between $\mathrm{C} 2$ domains of other molecules, except for hetero-oligomerization among the C2 domains of synaptotagmin family members (Chapman, 2002; Wu et al., 2003). The physiological role of the interaction between PRIP-C2 and Syt1-C2s currently remains unclear. However, a previous study strongly suggested that PRIP may play an inhibitory role in the participation of synaptotagmin in exocytosis, i.e., Syt1 was incorporated in the immunocomplex containing t-SNARE proteins and PRIP, and the amount of Syt1 in the immunocomplex was increased when PRIP was omitted using a PRIP-KO

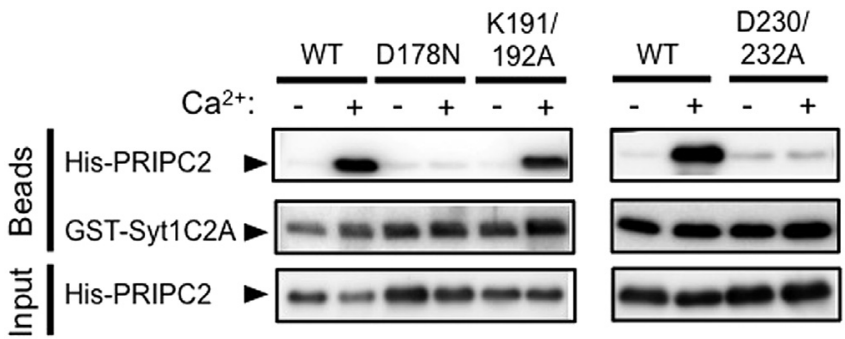

Fig. 4. Interaction between PRIP-C2 and Syt1-C2 mutants. A GST pull-down assay was performed as in Fig. 1 using GST-Syt1-C2A mutants. 
mouse brain as the source for immunoprecipitation (Zhang et al., 2013). Thus, further studies are required to clarify the molecular mechanism by which PRIP, Syt 1, and t-SNARE proteins are coordinated to form a complex, which will, in turn, lead to the exact mechanism underlying the $\mathrm{Ca}^{2+}$-triggered exocytosis regulated by these molecules being elucidated.

\section{Conflict of interest}

\section{Authors have no conflict of interest.}

\section{Acknowledgments}

The present study was supported by KAKENHI from the Japan Society for the Promotion of Science to MH (24229009), HT (24592805), and GJ (25861758), Takeda Science Foundation (to HT), and the Ichiro Kanehara Foundation (to HT). DW is a recipient of the Hirose International Scholarship.

\section{References}

Bai J, Chapman ER. The C2 domains of synaptotagmin-partners in exocytosis. Trends Biochem Sci 2004;29:143-51.

Brose N, Petrenko AG, Sudhof TC, Jahn R. Synaptotagmin: a calcium sensor on the synaptic vesicle surface. Science 1992;256: $1021-5$.

Carr CM, Rizo J. At the junction of SNARE and SM protein function. Curr Opin Cell Biol 2010;22:488-95.

Chapman ER. Synaptotagmin: a Ca(2+) sensor that triggers exocytosis? Nat Rev Mol Cell Biol 2002;3:498-508.

Chapman ER, Desai RC, Davis AF, Tornehl CK. Delineation of the oligomerization, AP-2 binding, and synprint binding region of the C2B domain of synaptotagmin. J Biol Chem 1998;273:32966-72.

Chapman ER, Jahn R. Calcium-dependent interaction of the cytoplasmic region of synaptotagmin with membranes. Autonomous function of a single C2-homologous domain. J Biol Chem 1994;269:5735-41.

Coudevylle N, Montaville P, Leonov A, Zweckstetter M, Becker S. Structural determinants for $\mathrm{Ca}^{2+}$ and phosphatidylinositol 4,5bisphosphate binding by the C2A domain of rabphilin-3A. J Biol Chem 2008;283:35918-28.

Davletov BA, Sudhof TC. A single C2 domain from synaptotagmin I is sufficient for high affinity $\mathrm{Ca}^{2+} /$ phospholipid binding. J Biol Chem 1993;268:26386-90.

Deak F, Shin OH, Tang J, Hanson P, Ubach J, Jahn R, et al. Rabphilin regulates SNARE-dependent re-priming of synaptic vesicles for fusion. EMBO J 2006;25:2856-66.

Desai RC, Vyas B, Earles CA, Littleton JT, Kowalchyck JA, Martin TF, et al. The C2B domain of synaptotagmin is a Ca(2+)-sensing module essential for exocytosis. J Cell Biol 2000;150:1125-36.

Doira N, Kanematsu T, Matsuda M, Takeuchi H, Nakano H, Ito Y, et al. Hyperinsulinemia in PRIP-1 gene deleted mice. Biomed Res Tokyo 2001;22:157-65.

Essen LO, Perisic O, Lynch DE, Katan M, Williams RL. A ternary metal binding site in the C2 domain of phosphoinositide-specific phospholipase C-delta1. Biochem 1997;36:2753-62.

Fernandez I, Arac D, Ubach J, Gerber SH, Shin O, Gao Y, et al. Three-dimensional structure of the synaptotagmin 1 C2B-domain: synaptotagmin 1 as a phospholipid binding machine. Neuron 2001;32:1057-69.

Fernandez-Chacon R, Konigstorfer A, Gerber SH, Garcia J, Matos MF, Stevens CF, et al. Synaptotagmin I functions as a calcium regulator of release probability. Nature 2001;410:41-9.

Friedrich R, Groffen AJ, Connell E, van Weering JR, Gutman O, Henis YI, et al. DOC2B acts as a calcium switch and enhances vesicle fusion. J Neurosci 2008;28:6794-806.

Fujii M, Kanematsu T, Ishibashi H, Fukami K, Takenawa T, Nakayama KI, et al. Phospholipase C-related but catalytically inactive protein is required for insulin-induced cell surface expression of gamma-aminobutyric acid type A receptors. J Biol Chem 2010;285:4837-46.

Fukuda M, Aruga J, Niinobe M, Aimoto S, Mikoshiba K. Inositol-1,3,4,5-tetrakisphosphate binding to C2B domain of IP4BP/ synaptotagmin II. J Biol Chem 1994;269:29206-11.

Gao J, Takeuchi H, Zhang Z, Fukuda M, Hirata M. Phospholipase C-related but catalytically inactive protein (PRIP) modulates synaptosomal-associated protein 25 (SNAP-25) phosphorylation and exocytosis. J Biol Chem 2012;287:10565-78.

Hay JC, Martin TF. Phosphatidylinositol transfer protein required for ATP-dependent priming of Ca(2+)-activated secretion. Nature 1993;366:572-5.

Holz RW, Hlubek MD, Sorensen SD, Fisher SK, Balla T, Ozaki S, et al. A pleckstrin homology domain specific for phosphatidylinositol 4, 5-bisphosphate (PtdIns-4,5- $\mathrm{P}_{2}$ ) and fused to green fluorescent protein identifies plasma membrane PtdIns-4,5$\mathrm{P}_{2}$ as being important in exocytosis. J Biol Chem 2000;275:17878-85.

Hong W. SNAREs and traffic. Biochim Biophys Acta 2005;1744:493-517.

James DJ, Khodthong C, Kowalchyk JA, Martin TF. Phosphatidylinositol 4,5-bisphosphate regulates SNARE-dependent membrane fusion. J Cell Biol 2008;182:355-66.

James DJ, Kowalchyk J, Daily N, Petrie M, Martin TF. CAPS drives trans-SNARE complex formation and membrane fusion through syntaxin interactions. Proc Natl Acad Sci USA 2009;106:17308-13.

Kanematsu T, Fujii M, Mizokami A, Kittler JT, Nabekura J, Moss SJ, et al. Phospholipase C-related inactive protein is implicated in the constitutive internalization of GABAA receptors mediated by clathrin and AP2 adaptor complex. J Neurochem 2007;101: $898-905$ 
Kanematsu T, Jang IS, Yamaguchi T, Nagahama H, Yoshimura K, Hidaka K, et al. Role of the PLC-related, catalytically inactive protein p130 in GABA(A) receptor function. EMBO J 2002;21:1004-11.

Kanematsu T, Misumi Y, Watanabe Y, Ozaki S, Koga T, Iwanaga S, et al. A new inositol 1,4,5-trisphosphate binding protein similar to phospholipase C-delta 1. Biochem J 1996;313(Pt 1):319-25.

Kanematsu T, Takeya H, Watanabe Y, Ozaki S, Yoshida M, Koga T, et al. Putative inositol 1,4,5-trisphosphate binding proteins in rat brain cytosol. J Biol Chem 1992;267:6518-25.

Kanematsu T, Yasunaga A, Mizoguchi Y, Kuratani A, Kittler JT, Jovanovic JN, et al. Modulation of GABA(A) receptor phosphorylation and membrane trafficking by phospholipase C-related inactive protein/protein phosphatase 1 and $2 \mathrm{~A}$ signaling complex underlying brain-derived neurotrophic factor-dependent regulation of GABAergic inhibition. J Biol Chem 2006; 281:22180-9.

Kim DK, Catterall WA. $\mathrm{Ca}^{2+}$-dependent and -independent interactions of the isoforms of the alpha1A subunit of brain $\mathrm{Ca}^{2+}$ channels with presynaptic SNARE proteins. Proc Natl Acad Sci USA 1997;94:14782-6.

Malsam J, Kreye S, Sollner TH. Membrane fusion: SNAREs and regulation. Cell Mol Life Sci 2008;65:2814-32.

Matsuda M, Tsutsumi K, Kanematsu T, Fukami K, Terada Y, Takenawa T, et al. Involvement of phospholipase C-related inactive protein in the mouse reproductive system through the regulation of gonadotropin levels. Biol Reprod 2009;81:681-9.

Rizo J, Chen X, Arac D. Unraveling the mechanisms of synaptotagmin and SNARE function in neurotransmitter release. Trends Cell Biol 2006;16:339-50.

Schiavo G, Gmachl MJ, Stenbeck G, Sollner TH, Rothman JE. A possible docking and fusion particle for synaptic transmission. Nature 1995;378:733-6.

Schiavo G, Gu QM, Prestwich GD, Sollner TH, Rothman JE. Calcium-dependent switching of the specificity of phosphoinositide binding to synaptotagmin. Proc Natl Acad Sci USA 1996;93:13327-32.

Sheng ZH, Yokoyama CT, Catterall WA. Interaction of the synprint site of $\mathrm{N}$-type $\mathrm{Ca}^{2+}$ channels with the C2B domain of synaptotagmin I. Proc Natl Acad Sci USA 1997;94:5405-10.

Sudhof TC. Synaptotagmins: why so many? J Biol Chem 2002;277:7629-32.

Sugiyama G, Takeuchi H, Nagano K, Gao J, Ohyama Y, Mori Y, et al. Regulated interaction of protein phosphatase 1 and protein phosphatase 2A with phospholipase C-related but catalytically inactive protein. Biochem 2012;51:3394-403.

Sgiyama G, Takeuchi H, Kanematsu T, Gao J, Matsuda M, Hirata M. Phospholipase C-related but catalytically inactive protein, PRIP as a scaffolding protein for phospho-regulation. Adv Biol Regul 2013;53:331-40.

Sutton RB, Davletov BA, Berghuis AM, Sudhof TC, Sprang SR. Structure of the first C2 domain of synaptotagmin I: a novel Ca ${ }^{2+} /$ phospholipid-binding fold. Cell 1995;80:929-38.

Sutton RB, Ernst JA, Brunger AT. Crystal structure of the cytosolic C2A-C2B domains of synaptotagmin III. Implications for $\mathrm{Ca}(+2)-$ independent snare complex interaction. J Cell Biol 1999;147:589-98.

Takeuchi H, Kanematsu T, Misumi Y, Yaakob HB, Yagisawa H, Ikehara Y, et al. Localization of a high-affinity inositol 1,4,5trisphosphate/inositol 1,4,5,6-tetrakisphosphate binding domain to the pleckstrin homology module of a new $130 \mathrm{kDa}$ protein: characterization of the determinants of structural specificity. Biochem J 1996;318(Pt 2):561-8.

Takeuchi H, Oike M, Paterson HF, Allen V, Kanematsu T, Ito Y, et al. Inhibition of Ca(2+) signalling by p130, a phospholipase-Crelated catalytically inactive protein: critical role of the p130 pleckstrin homology domain. Biochem J 2000;349:357-68.

Ubach J, Lao Y, Fernandez I, Arac D, Sudhof TC, Rizo J. The C2B domain of synaptotagmin I is a Ca ${ }^{2+}$-binding module. Biochem 2001;40:5854-60.

Ubach J, Zhang X, Shao X, Sudhof TC, Rizo J. $\mathrm{Ca}^{2+}$ binding to synaptotagmin: how many $\mathrm{Ca}^{2+}$ ions bind to the tip of a C2domain? EMBO J 1998; 17:3921-30.

Uji A, Matsuda M, Kukita T, Maeda K, Kanematsu T, Hirata M. Molecules interacting with PRIP-2, a novel Ins $(1,4,5) \mathrm{P}_{3}$ binding protein type 2: comparison with PRIP-1. Life Sci 2002;72:443-53.

Walter AM, Groffen AJ, Sorensen JB, Verhage M. Multiple $\mathrm{Ca}^{2+}$ sensors in secretion: teammates, competitors or autocrats? Trends Neurosci 2011;34:487-97.

Weber T, Zemelman BV, McNew JA, Westermann B, Gmachl M, Parlati F, et al. SNAREpins: minimal machinery for membrane fusion. Cell 1998;92:759-72.

Wu Y, He Y, Bai J, Ji SR, Tucker WC, Chapman ER, et al. Visualization of synaptotagmin I oligomers assembled onto lipid monolayers. Proc Natl Acad Sci USA 2003;100:2082-7.

Yoshimura K, Takeuchi H, Sato O, Hidaka K, Doira N, Terunuma M, et al. Interaction of p130 with, and consequent inhibition of, the catalytic subunit of protein phosphatase 1alpha. J Biol Chem 2001;276:17908-13.

Zhang Z, Takeuchi H, Gao J, Wang D, James DJ, Martin TF, et al. PRIP (phospholipase C-related but catalytically inactive protein) inhibits exocytosis by direct interactions with syntaxin 1 and SNAP-25 through its C2 domain. J Biol Chem 2013;288: 7769-80. 